\title{
Hubungan Kontrol Diri dan Kesepian dengan Nomophobia Pada Remaja
}

\section{Relationship between Self Control and Loneliness with Nomophobia in Adolescents}

\author{
Achmad Fathoni ${ }^{*}$, Siti Nur Asiyah ${ }^{1}$ \\ ${ }^{1}$ Fakultas Psikologi dan Kesehatan UIN Sunan Ampel Surabaya \\ fathony446@gmail.com
}

\begin{abstract}
Abstrak
Penelitian ini memiliki tujuan yaitu untuk mengetahui apakah terdapat hubungan antara kontrol diri dan kesepian dengan nomophobia pada remaja. Pada penelitian ini menggunakan metode kuantitatif korelasional. jumlah responden adalah 346 siswa/siswi di SMK Negeri 12 Surabaya, SMA Negeri 22 Surabaya, dan MAN Kota Surabaya. Skala yang digunakan dalam penelitian ini ada tiga, yaitu skala kontrol diri yang didasarkan pada aspek-aspek konrtol diri menurut teori Tangney, (2004), dan skala kesepian yang disusun dari aspek-aspek menurut Perlman \& Peplau, (1981) yang diadopsi dari Muhammad Abdul Jalil Jauhar, (2019), sedangkan penyusunan skala nomophobia didasarkan pada skala NMP-Q (Nomophobia Questionnair) dari Yildrim, (2014) yang diadopsi dari Nadya Atikah Putri, (2019). Teknik analisis data dalam penelitian ini menggunakan analisis regresi linier berganda dengan proses SPSS 16.0 for windows. hasil penelitian menunjukkan bahwa ada hubungan antara kontrol diri dan kesepian dengan nomophobia pada remaja di di SMK Negeri 12 Surabaya, SMA Negeri 22 Surabaya, dan MAN Kota Surabaya dengan uji hipotesis korelasi parsial antara kontrol diri dengan nomophobia sejumlah 0.137 sedangkan signifikansi memiliki nilai sejumlah 0,006 , yang artinya terdapat hubungan positif signifikan antara nomophobia dengan kontrol diri pada remaja, kemudian pada variabel kesepian dengan nomophobia mempunyai nilai korelasi sejumlah 0,288 dan nilai signifikansi sejumlah 0,000, yang artinya terdapat hubungan positiif signifikan antara nomophobia dengan kesepian pada remaja. Pada uji korelasi regresi simultan diketahui F-hitung dengan nilai 23.572 dan nilai $\mathrm{F}$ tabel sejumlah 3,022. Hal ini menunjukkan bahwa diperoleh hubungan signifikan antara Kontrol Diri dan Kesepian dengan nomophobia pada remaja. Sumbangan efektif yang diberikan dari variabel kontrol diri sebesar 2,7\%. Sedangkan sumbangan efektif variabel kesepian sebesar 9,4\%. Kedua variabel ini memberikan sumbangan efektif, namun sumbangan efektif yang diberikan oleh variabel kesepian lebih banyak dari pada kontrol diri. Selebihnya itu variabel nomophobia dipengaruhi oleh berbagai faktor lain yang tidak diungkap pada penelitian ini.
\end{abstract}

Kata kunci: Kontrol Diri, Kesepian, dan Nomophobia

\begin{abstract}
This study aims to determine whether there is a relationship between self-control and loneliness with nomophobia in adolescents. This research uses correlational quantitative method. The number of respondents was 346 students at SMK Negeri 12 Surabaya, SMA Negeri 22 Surabaya, and MAN Surabaya City. There are three scales used in this study, namely the self-control scale which is based on aspects of self-control according to Tangney's theory, (2004), and the loneliness scale which is composed of aspects according to Perlman \& Peplau, (1981) which was adopted from Muhammad Abdul Jalil Jauhar, (2019), while the preparation of the nomophobia scale is based on the NMP-Q (Nomophobia Questionnair) scale from Yildrim, (2014) which was adopted from Nadya Atikah Putri, (2019). The data
\end{abstract}


analysis technique in this study used multiple linear regression analysis with SPSS 16.0 for windows process. The results showed that there was a relationship between self-control and loneliness with nomophobia in adolescents at SMK Negeri 12 Surabaya, SMA Negeri 22 Surabaya, and MAN Surabaya City with a partial correlation hypothesis test between self-control and nomophobia of 0.137 while the significance value was 0.006, which means that there is a significant positive relationship between nomophobia and self-control, then the loneliness variable with nomophobia has a correlation value of 0.288 and a significance value of 0.000 , which means that there is a significant positive relationship between nomophobia and loneliness in adolescents. Meanwhile, in the simultaneous regression correlation test, it is known that the F-count is 23,572 and the F-table value is 3.022. This shows that there is a significant relationship between Self-Control and Loneliness with nomophobia in adolescents. The effective contribution given from the self-control variable is 2.7\%. While the effective contribution of the lonely variable is $9.4 \%$. Both of these variables provide effective contributions, but the effective contribution given by the lonely variable is more than self-control. The rest, the nomophobia variable is influenced by various other factors that are not revealed in this study.

Keywords: Self Control, Loneliness, and Nomophobia

\section{Pendahuluan}

Nomophobia adalah suatu ketidaknyamanan, kegelisahan, ketakutan atau kesedihan yang disebabkan karena tidak dapat berhubungan dengan telepon genggam smartphone. Nomophobia merupakan suatu keadaan dimana timbulnya perasaan cemas jika dijauhkan dari smartphone. Sebagai contoh jika sesorang dalam suatu area tanpa terkoneksi jaringan internet atau kehabisan baterai pada smartphone, maka akan merasa dirinya terancam bahkan ada yang mengalami kecemasan (phobia), depresi, bahkan gangguan jiwa, yang dapat mempengaruhi kesehatan psikologis (Ramaita et al., 2019). Saat ini seseorang semakin mudah berinteraksi dengan orang lain di manapun dan kapan pun melalui media sosial, game dan lain sebagainya menggunakan smartphone yang dimaksud seperti mobile phone chatting. Beberapa media sosial yang semakin berkembang saat ini, antara lain yaitu Facebook, Twitter, Instagram, dan YouTube. Remaja sering kali terbuai dengan fitur yang ada pada smartphone seperti media sosial, games, dan internet. Penggunaan tiga fitur tersebut mungkin akan bisa bermanfaat jika berada pada batasan yang normal tapi, jika berlebihan maka akan dapat mengganggu psikologis pengguna dalam kehidupan sehari-hari, baik kehidupan pribadi, sosial, maupun akademik (Permatasari et al., 2019).

Masa remaja mempunyai beberapa tugas perkembangan yang harus dicapai dan dipenuhi dalam tahap-tahap perkembangan yang ada. Menururt Hurlock, (2011) masa remaja dimulai dengan masa remaja awal dengan usia (12-14 tahun), kemudian masa remaja tengah dengan usia (15-17 tahun), dan masa remaja akhir dengan usia (18-21tahun). Siswa/siswi pada jenjang sekolah menengan atas berada pada masa remaja tengah atau madya, dengan rentangan usianya yaitu 15-17 tahun. Remaja adalah suatu masa transisi dari masa anak-anak menjadi dewasa awal dan mencapai kematangan emosional, mental, fiisk, dan sosial. Tugas perkembangan masa remaja dapat difokuskan pada sikap dan lebih meninggalkan perilaku kekanak-kanakan serta berusaha untuk mampu dalam hal bersikap dan berperilaku secara desawa.

Penggunaan smartphone secara tidak langsung bisa menjadi sebuah eksistensi seorang individu dalam kelompoknya. Sebuah penelitian yang dilakukan oleh salah satu organisasi di Negara Inggris mengungkapkan bahwa kecemasan yang diderita oleh pengguna smartphone menemukan bahwa hampir 53\% pengguna smartphone di Negara Inggris cenderung merasa cemas saat kehilangan smartphone, tidak mempunyai jangkauan jaringan, dan kehabisan baterai (Bivin, 2013).

Nomophobia akhir-akhir ini telah dipakai untuk mewakili kecemasan atau ketidaknyamanan dikarenakan tidak berada dekat dengan perangkat komunikasi virtual yaitu smartphone (King \& Valenca, 2013). Berbagai bentuk Fitur dan fungsi yang terdapat pada perangkat smartphone dapat membagikan kemudahan untuk melakukan setiap kegiatan dalam kehidupan sehari-sehari. Misalnya mengirim pesan kepada pihak lain, melihat atau mengirimkan sebuah email, menelpon, mencari berbagai informasi secara online, untuk menata jadwal kegiatan, melakukan penelusuran diinternet, berbelanja online, bermain game online maupun offline, dan lain sebagainya. 
Dalam artikel yang ditulis Dian, (2021) menyatakan hal ini perlu kita sadari bahwa kerusakan yang terjadi dikarenakan tidak adanya filter yang menjaga fitrah manusia. Sehingga pada akhirnya para remaja yang seharusnnya sedang dalam masa mencari jati diri malah terjerumus kebebasan dan ingin terlihat gaul. Remaja saat ini menjadi korban dari kemajuan teknologi di era globalisasi. Hal ini disebabkan kurangnya ilmu agama untuk memfilter hal-hal yang kurang baik.

Sejatinya masa pandemi ini adalah waktu untuk memperbaiki diri dan muhasabah seperti membaca dan menghafal al-Qur'an, membuat kerajinan atau karya, membaca buku dan lain sebagainya. Saat ini kita seakan dihembuskan dengan ide yang menyejukkan. Tapi sejatinnya menyesatkan bagi mereka yang mudah terpengaruh dan tidak berpegang dengan tali aqidah. Di samping itu hal ini dapat membuang-buang waktu. Dalam sebuah Al-Qur'an surat Al-Ashr ayat 1 sampai dengan 3 Allah SWT berfirman:

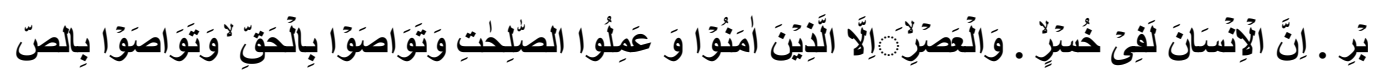

Artinya, Dan demi masa, Sesuungguhnya manusia berada dalam kerugian. Kecuali orang-orang yang beriman dan mengerjakan kebaikan, serta saling manasehati untuk kebenaran dan kesabaran.

Hal ini merupakan sebuah perilaku maupun kegiatan yang mana berlebihan dalam menggunakan smartphone. Salah satu kecenderungan remaja saat menggunakan smartphone secara berlebihan yaitu siswa lebih banyak menghabiskan waktunya dengan smartphone, sehingga akhirnya siswa merasa kesukaran dalam belajar, baik di rumah maupun di sekolah dan menimbulkan kemalasan. Selain itu hal ini juga membuat remaja tidak mampu beradaptasi dengan lingkungan sosialnya. Padahal diharapkan remaja mampu untuk menjadi pribadi yang dapat menciptakan interaksi sosial yang terbuka, sama-sama mendukung, dan saling memberi perhatian terhadap kebutuhan teman (Mutawally, 2020).

Menururt Asosiasi Penyelenggara Jasa Internet Indonesia (APJII) mengatakan bahwa berdasarkan karakter kabupaten/kota terdapat sejumlah $70.96 \%$ masyarakat urban yang memakai tablet/smartphone, kemudian sejumlah $45,42 \%$ bagi masyarakat rural-urban, sedangkan $42,06 \%$ masyarakat rural. Disamping itu penggunaan laptop atau komputer memiliki kisaran 31,55\% untuk masyarakat urban, kemudian masyarakat rural urban sejumlah $23,42 \%$, sedangkan masyarakat rural sejumlah 23,83\%. Perangkat yang digunakan untuk mengakses internet menggunakan tablet atau smartphone pribadi sebesar 44,16\%, dan untuk mengakses internet mengunakan laptop atau komputer pribadi sebesar 4,49\% (APJII, 2017).

Penggunaan smartphone yang terlalu berlebihan dapat berdampak negatif, sehingga menggangu aktifitas dalam kehidupan sehari-hari. Dalam menggunakan smartphone, dibutuhkan sebuah pengendalian diri yang baik supaya dapat membatasi diri dalam penggunaan smartphone yang berlebihan serta menghindari akibat negatifnya. Dari sinilah, kontrol diri menjadi salah satu faktor yang penting untuk mengontrol perilaku seseorang, terutama dalam menggunakan smartphone (Agusta, 2016).

Individu yang mengalami nomophobia, mempunyai sebuah karakteristik klinis, sebagai contohnya memakai smartphone secara energik dan membuang waktu untuk menggunakan smartphone, individu merasakan cemas ketika smartphone sedang tidak dapat digunakan karena jaringan yang lemah, cenderung selalu membawa charger ketika pergi, tetap melihat notifikasi yang masuk pada smartphone, lebih memilih untuk berinteraksi lewat online dibandingkan dengan secara langsung atau tatap muka, serta mengeluarkan biaya yang besar demi menggunakan smartphone. Kelebihan yang ada pada smartphone menjadikan pengguna yang meningkat dan pada pernyataan di atas dapat diartikan bahwa para pengguna smartphone saat ini menderita nomophobia, karena pengguna akan merasa kehilangan benda yang sangat penting apabila smartphone berada jauh dari jangkaunnya.

Hal tersebut sesuai dengan interview awal yang peneliti lakukan di tiga sekolahan yaitu SMAN 22 Surabaya, SMKN 12 Surabaya, dan MAN Kota Surabaya dengan beberapa siswa/siswi dan guru dalam jenjang sekolah menengan ke atas. Salah satu guru pada jenjang sekolah menengah ke atas di Surabaya mengatakan bahwa terdapat siswa yang bermain smartphone saat pelajaran sekoah berlangsung. Kebanyakan mereka sedang mengakses youtube dan bermain games. Selain itu peneliti juga telah melakukan wawancara dengan siswa/siswi di tiga sekolahan tersebut, mereka merasa cemas 
apabila tidak membawa smartphone saat bepergian dan merasa khawatir jika tidak dapat mengakses internet atau media sosial lantaran takut apabaila tidak dapat menghubungi temannya, mereka selalu membawa charger untuk menambah daya batrai ketika smartphone sedang lowbet. Hal ini dikarenakan semua kebutuhan mereka saat ini berada pada smartphone, sehingga sampai pergi ke kamar mandi pun membawa smartphone. Mereka sering merasakan smartphonenya berdering layaknya ada pesan atau notifikasi masuk, hal ini disebut juga dengan phantom pocket vibration syndrome (Sumber dari Hasil Interview dengan Siswa/siswi SMK Negeri 12 Surabaya, SMA Negeri 22 Surabaya, dan MAN Kota Surabaya. Desember 2020).

Seperti yang dikatakan oleh dr. Jimmy EBH, Sp.S neurolog RSUP dr. Kariadi Semarang yang dilansir dari Epaper Suara Merdeka bahwa nomophobia juga bisa memberikan dampak negatif karena gelombang electromagnet yang dihasilkan oleh smartphone dapat menyebabkan sakit kepala, gangguan system imun, kelelahan, dan iritasi mata. Tingkatan yang lebih jauh dari dampak negatif nomophobia adalah bisa meningkatkan resiko penyakit seperti tumor otak, Alzheimer, gangguan tidur, kanker, bahkan bisa membunuh sperma (Asih \& Fauziah, 2017).

Melihat dampak negatif dari pengguna smartphone di atas, kontrol diri menjadi peran penting dalam mengendalikan pengguna smartphone agar sesuai dengan kebutuhan. Menurut Kail (2010) kontrol diri adalah kemampuan individu dalam mengendalikan perilaku ataupun menahan diri dari godaan. Dalam hal ini kontrol diri yang baik akan dapat membantu individu untuk membatasi diri dari penggunaan smartphone dan sosial media yang berlebihan serta menghindari efek buruknya (Aldianita \& Maryatmi, 2019).

Selain itu, penggunaan smartphone bisa mengurangi rasa kesepian. Artinya penggunaan smartphone secara berlebihan bisa jadi digunakan untuk menyembuhkan rasa kesepian dan untuk mengatasi perasaan yang menggangu individu, hal ini dikarenakan sebuah smartphone dapat memberi bentuk sosialisasi yang beda. Menurut Peplau \& Perlman, (1982) sebuah kesepian merupakan respon tentang ketidakselarasan antara hubungan yang diinginkan oleh individu dengan lingkungan sosialnya. Berdasarkan pengertian di atas kesepian dapat dimaknai sebagai tindakan oleh perasaan manusia yang disebabkan tidak adanya hubungan yang diinginkan dan persahabatan yang berarti antar individu (Saripah, Nur Aida \& Pratiwi, 2020). Menurut Durak, (2018) dalam Nadia, (2020) mengatakan bahwa kesepian dapat muncul disebabkan karena kecenderungan terhadap smartphone, ia juga mengatakan bahwa terdapat tiga faktor yang dapat mempengaruhi munculnya kecenderungan terhadap smartphone, salah satunya yaitu sikap kesepian.

Seseorang akan menggunakan smartphone dan berpaling ke dunia maya apabila tidak dapat memenuhi kebutuhan di dalam hubungan sosial. Hal ini akan menjadikan seseorang untuk menghindari dunia nyat (Durak, 2018). Pendapat yang tersebut di atas didukung oleh sebuah penelitian yang dilakukan pada 527 responden, dengan hasil yang menunjukkan bahwa kesepian memiliki hubungan yang signifikan dengan penggunaan ponsel (Donder, dkk., 2013). Faktor-faktor lain yang bisa menyebabkan terjadinya keterkaitan terhadap smartphone yaitu kontrol diri yang rendah (Yuwanto, 2010). Seseorang yang tidak cakap untuk melakukan kontrol diri saat menggunakan smartphone atau seseorang yang mempuyai kontrol diri rendah dapat lebih gampang menderita ketergantungan smartphone. Pernyataan ini didukung dengan penelitian yang dilakukan oleh Asih dan Fauziah, (2017) kepada 457 mahasiswa Jurusan Ilmu Komunikasi Fakultas Ilmu Sosial dan Ilmu Politik Universitas Diponegoro dengan hasil penelitian yang menunjukkan hubungan signifikan ke arah negatif antara kontrol diri dengan ketergantungan smartphone, sehingga dapat dikatakan jika semakin tinggi kontrol diri seseorang, maka tingkat ketergantungan smartphone yang dialami juga semakin rendah, demikian sebaliknya apabila semakin rendang kontrol diri maka semakin tinggi ketergantungan smartphone.

Beberapa penelitian terdahulu yang mengungkap nomophobia seperti yang ditulis oleh Aida Nur Saripah \& Lila Pratiwia, (2020) dengan judul "Hubungan Kesepian Dan Nomophobia Pada Mahasiswa Generasi Z" mempunyai hasil bahwa terdapat korelasi positif signifikan antara kesepian dan nomophobia, kemudian penelitian yang dilakukan oleh Dwi Christina Rahayuningrum \& Annisa Novita Sary, (2019) tentang "Studi Tingkat Kecemasan Remaja Terhadap No-Mobile Phone (Nomophobia) Di Sma Negeri Kota Padang" mempunyai hasil terdapat hubungan antara tingkat kecemasan remaja Sekolah Menengah Atas terhadap nomophobia di Kota Padang. Kemudian penelitian yang ditulis oleh Intan Permatasari, Yusmansyah, \& Ratna Widiastuti, (2019) tentang "Penggunaan Bimbingan Kelompok Teknik Self Management untuk Menurunkan Kecenderungan Nomophobia Siswa SMA” yang mempunyai hasil bahwa layanan bimbingan kelompok teknik self management bisa menurunkan 
kecenderungan nomophobia pada siswa kelas X SMA Negeri 1 Gedongtataan pada tahun pelajaran 2019/2020.

Penelitian ini ditujukan untuk mengetahui: 1) Hubungan Kontrol Diri dengan Nomophobia Pada Remaja. 2) Hubungan Kesepian dengan Nomophobia Pada Remaja. 3) Hubungan Kontrol Diri dan Kesepian dengan Nomophobia Pada Remaja. Sehingga dari literature review yang telah dilakukan dan dari penjelasan di atas maka hipotesis yang diajukan dalam penelitian ini adalah: 1) Terdapat hubungan yang signifikan ke arah negatif antara Kontrol Diri dengan Nomophobia Pada Remaja. 2) Terdapat hubungan yang signifikan ke arah positif antara Kesepian dengan Nomophobia Pada Remaja. 3) Terdapat hubungan yang signifikan antara Kontrol Diri dan Kesepian dengan Nomophobia Pada Remaja.

Berdasarkan fenomena yang terjadi pada remaja khususnya sekolah menengah atas yang mengalami nomophobia, penelitian ini menjadi penting dilaksanakan karena masih kurangnyanya studi terhadap persoalan pada remaja SMA, SMK, dan MAN. Penelitian sebelumnya melihat variabel kontorl diri dan kesepian secara terpisah akan tetapi penelitian kali ini akan melihat variable kontrol diri dan kesepian bekerja di dalam terbentunya sebuah nomophobia secara bersamaan. Di samping itu beberapa penelitian yang tertera juga menunjukkan perbedaan yang menjadikan penyebab nomophobia baik secara lokasi, subjek penelitian hingga masa pandemi. Dengan demikian tema penelitian ini akan melihat hubungan antara kontrol diri dan kesepian dengan nomophobia pada remaja.

\section{Metode Penelitian}

Penelitian ini menggunakan metode analisis regresi linier berganda dengan pendekatan kuantitatif korelasional. Subjek penelitian ini adalah remaja yang bersekolah di SMAN 22 Surabaya, SMKN 12 Surabaya, dan MAN Kota Surabaya dengan jumlah sampel 346 siswa. Penelitian ini menggunakan skala berupa kuesioner atau angket yang dibuat dengan cara mengadopsi dari penelitian sebelumnya yaitu Nadya Atika Putri (2019) dengan judul "Hubungan antara Self Control dengan Kecenderungan Nomophobia (No Mobile Phone Phobia) Pada Mahasiswa". Dengan nilai reliabilitas sebesar 0,941. Hal ini sebagai acuan untuk mengadopsi pada instrument variabel Nomophobia dengan aspek yang sesuai dengan teori Yildrim, (2014).

Instrument selanjutnya mengadopsi dari Muhammad Abdul Jalil Jauhar (2019) dengan judul "Hubungan Self-Esteem dengan Loneliness Pada Santri Baru Madrasah Aliyah Pondok Pesantren Mambaus Sholihin Gresik". Dengan nilai reliabilitas sebesar 0,929. Hal ini sebagai acuan untuk mengadopsi pada instrument variabel Kesepian dengan aspek yang sesuai dengan teori yang digunakan oleh Perlman \& Peplau, (1981). Dan untuk instarumen Kontrol Diri dibuat berdasarkan lima aspek menurut Tangney, dkk (2004).

Data yang telah terkumpul kemudian diolah secara kuantitatif menggunakan Program SPSS for windows 16.0. Untuk menguji hipotesis peneliti menggunakan beberapa Teknik analisis statistik yaitu analisis regresi linier berganda di mana hal ini merupakan prosedur yang digunakan untuk menguji besarnya koefisien-koefisien yang dihasilkan oleh persamaan yang bersifat linier yang melibatkan dua atau lebih variabel bebas untuk digunakan sebagai alat prediksi besarnya nilai variabel terikat (Muhid, 2012).

Sebelum melakukan analisis dengan regresi linier berganda maka akan dilakukan uji prasyarat terlebih yang meliputi: uji normalitas, uji linieritas, uji Multikolinearitas, dan uji Heteroskedastisitas. Uji prasyarat ini digunakan untuk dapat mengetahui apakah hasil dari analisis data untuk uji hipotesis dapat dilanjutkan atau tidak.

\section{Hasil Penelitian}

Berdasarkan penelitian yang dilakukan terhadap variable kontrol diri dan kesepian denga nomophobia maka di dapat data correlation nilai masing-masing variable diantaranya sebagai berikut: 
Tabel 1. Correlation

\begin{tabular}{ccccc}
\hline \multicolumn{5}{c}{ Correlations } \\
\hline & & NOMOPHOBIA & KONTROL DIRI & KESEPIAN \\
\hline Pearson Correlation & NOMOPHOBIA & 1.000 & .137 & .288 \\
& KONTROL DIRI & .137 & 1.000 & -.191 \\
& KESEPIAN & .288 & -.191 & 1.000 \\
\hline \multirow{2}{*}{ Sig. (1-tailed) } & NOMOPHOBIA &. & .006 & .000 \\
& KONTROL DIRI & .006 &. & .000 \\
& KESEPIAN & .000 & .000 &. \\
\hline $\mathrm{N}$ & NOMOPHOBIA & 346 & 346 & 346 \\
& KONTROL DIRI & 346 & 346 & 346 \\
& KESEPIAN & 346 & 346 & 346 \\
\hline
\end{tabular}

antara lain:

Pada tabel di atas memuat nilai hubungan antara nomophobia, kontrol diri, dan kesepian,

a) Korelasi antara nomophobia (Y) dengan kontrol diri (X1) yaitu sebagai berikut:

Berdasarkan tabel di atas didapatkan korelasi sejumlah .137 dengan signifikansi 0,006. Dikarenakan signifikansi yang didapatkan memiliki nilai $>0,05$, maka HO berarti ditolak dan $\mathrm{Ha}$ berarti diterima. Yang mana hal ini memiliki makna terdapat suatu hubungan yang signifikan kea rah positif antara nomophobia dengan kontrol diri pada remaja di SMA Negeri 22 Surabaya, SMK Negeri 12 Surabaya, dan MAN Kota Surabaya.

b) Korelasi antara nomophobia (Y) dengan kesepian (X2) yaitu:

Table tersebut di atas memperlihatkan korelasi dengan nilai .288 dengan signifikansi 0,000. Dikarenakan signifikansi yang didapatkan memiliki nilai >0,05. Maka H0 berarti ditolak sedangkan Ha berarti diterima. Artinya, dalam penelitian ini memiliki makna terdapat hubungan signifikan kea rah positif antara nomophobia dengan kesepian pada remaja di SMA Negeri 22 Surabaya, SMK Negeri 12 Surabaya, dan MAN Kota Surabaya.

c) Korelasi antara kontrol diri (X1) dan kesepian (X2) yaitu sebagai berikut:

Pada tabel di atas dapat diketahui bahwa korelasi mempunyai nilai 1,000 dengan signifikansi 0,006. Dikarenakan signifikansi yang diperoleh memiliki nilai $>0,05$. Maka Ho berarti ditolak sedangkan Ha berarti diterima. Artinya, dalam penelitian ini memiliki makna terdapat hubungan yang signifikan antara kontrol diri dengan kesepian pada remaja di SMAN 22 Surabaya, SMKN 12 Surabaya, dan MAN Kota Surabaya.

Tabel 2. Anova

\begin{tabular}{|c|c|c|c|c|c|c|}
\hline & Model & $\begin{array}{c}\text { Sum of } \\
\text { Squares }\end{array}$ & $D f$ & Mean Square & $F$ & Sig. \\
\hline \multirow[t]{3}{*}{1} & Regression & 4460.620 & 2 & 2230.310 & 23.572 & $.000^{\mathrm{a}}$ \\
\hline & Residual & 32453.949 & 343 & 94.618 & & \\
\hline & Total & 36914.569 & 345 & & & \\
\hline
\end{tabular}

a. Predictors: (Constant), KESEPIAN, KONTROL DIRI

\section{b. Dependent Variable: NOMOPHOBIA}

Table tersebut menyatakan bahwasanya $\mathrm{F}$ hitung mempunyai nilai sejumlah 23.572 dengan signifikansi 0,000. Artinya adalah $>0,05$. Maka bisa dapat dikatakan Model Regresi tersebut bisa dipakai untuk memprediksi nilai nomophobia. Dengan arti lain Kontrol Diri dan Kesepian mempengaruhi Nomophobia pada remaja di SMA Negeri 22 Surabaya, SMK Negeri 12 Surabaya, dan MAN Kota Surabaya. 
Berdasarkan analisis statistik regresi linier berganda yang dilakukan terhadap hasil penelitian dapat dijelaskan melalui tabel berikut ini:

Tabel 3. Koefisien Determinasi

\begin{tabular}{cccccc}
\hline Model & $\mathrm{R}$ & $\mathrm{R}$ Square & $\begin{array}{c}\text { Adjusted } \mathrm{R} \\
\text { Square }\end{array}$ & $\begin{array}{c}\text { Std. Error of the } \\
\text { Estimate }\end{array}$ & Durbin-Watson \\
\hline 1 & $.348^{\mathrm{a}}$ & .121 & .116 & 9.72717 & 1.994 \\
\hline
\end{tabular}

a. Predictors: (Constant), KESEPIAN, KONTROL DIRI

Table tersebut memperlihatkan $\mathrm{R}$ Square memiliki nilai 0,121 dengan arti $12.1 \%$ dari variabel nomophobia dipengaruhi kontrol diri dan kesepian. Sisanya sebesar $87.9 \%$ dipengaruhi variabel yang lain.

Tabel 4. Koefisien

\begin{tabular}{|c|c|c|c|c|c|c|c|c|c|}
\hline & \multirow[b]{2}{*}{ Model } & \multicolumn{2}{|c|}{$\begin{array}{l}\text { Unstandardized } \\
\text { Coefficients }\end{array}$} & \multirow{2}{*}{$\begin{array}{c}\begin{array}{c}\text { Standardized } \\
\text { Coefficients }\end{array} \\
\text { Beta }\end{array}$} & \multirow[b]{2}{*}{$\mathrm{t}$} & \multirow[b]{2}{*}{ Sig. } & \multicolumn{3}{|c|}{ Correlations } \\
\hline & & B & Std. Error & & & & $\begin{array}{l}\text { Zero- } \\
\text { order }\end{array}$ & Partial & Part \\
\hline \multirow[t]{3}{*}{ I } & (Constant) & 32.332 & 5.459 & & 5.923 & .000 & & & \\
\hline & $\begin{array}{c}\text { KONTROL } \\
\text { DIRI }\end{array}$ & .298 & .077 & .199 & 3.855 & .000 & .137 & .204 & .195 \\
\hline & KESEPIAN & .235 & .037 & .326 & $6.3 \mathrm{I} 4$ & .000 & .288 & .323 & .320 \\
\hline
\end{tabular}

a. Dependent Variable: NOMOPHOBIA

Tabel tersebut di atas menunjukkan Model Regresi diperoleh seperti di bawah ini:

$\mathrm{Y} \quad($ Nomophobia $)=32.332$

$\mathrm{X} 1 \quad$ (Kontrol Diri) $=.298$

$\mathrm{X} 2 \quad$ (Kesepian) $=.235$

$\mathrm{Y}=\mathrm{a}+\mathrm{b} 1 \mathrm{X} 1+\mathrm{b} 2 \mathrm{X} 2$

$\mathrm{Y}=32.332+.298+.2351)$

1. Konstanta sebesar 31.474 mengungkapkan, apabila tidak ada nilai kontrol diri dan kesepian. Maka nomophobia memiliki nilai 32.332, 2. Nilai Koefisien Regresi dengan jumlah 0.289 memberi makna bahwa tiap penjumlahan satu kontrol diri dapat menambah nomophobia dengan nilai 0.298 , 3. Nilai Koefisien Regresi dengan jumlah 0.234 juga memberi makna tiap penjumlahan satu kesepian dapat menambah nomophobia dengan nilai 0.235 .

Berdasarkan tabel ANOVA diatas, maka terdapat F-hitung dengan nilai 23.572. apabila tingkat keyakinan yang digunakan sebasar 95\%, a=5\% df (Degree of Freedom) 1 jumlah variabel-1 = 2 dan $\mathrm{df}$ (Degree of Freedom) $\mathrm{n}-\mathrm{k}-1=343$. N merupakan jumlah keseluruhan responden, kemudian $\mathrm{k}$ yaitu jumlah variabel bebas. Dari perhitungan di atas maka akan memperoleh nilai F-tabel dengan nilai 3,022. Dikarenakan nilai F-hitung lebih besar dari F-tabel maka H0 ditolak. Hal ini menunjukkan bahwa diperoleh hubungan signifikan antara Kontrol Diri dan Kesepian dengan Nomophobia Pada Remaja di SMAN 22 Surabaya, SMKN 12 Surabaya, dan MAN Kota Surabaya.

\section{Pembahasan}

Tujuan dari dilaksanakannya penelitian ini adalah mengetahui hubungan antara kontrol diri dan kesepian dengan nomophobia pada remaja di SMAN 22 Surabaya, SMKN 12 Surabaya, dan MAN Kota Surabaya yang berjumlah 2.307 siswa/siswi dan diambil 346 subjek. Metode yang digunakan adalah kuantitatif dengan teknik analisis Regresi Linier Berganda yang sebelumnya telah dilakukan uji prasyarat terlebih dahulu. Hasil uji normalitas yang dilakukan menunjukkan nilai signifikansi sebesar 0,597, dengan mempunyai nilai signifikansi $>0.05$ maka dapat dikatakan bahwa sebaran data pada variabel penelitian berdistribusi normal. Kemudian uji linieritas diperoleh hasil bahwa data antar variabel menunjukkan linier dengan nilai signifikansi $0.022>0.05$. 
selanjutnya adalah uji heteroskedastisitas yang menunjukkan bahwa gambar scatterplot terdapat titik-titik diatas dan dibawah angka nol pada sumbu Y, serta tidak membentuk pola tertentu yang teratur seperti (melebur, bergelombang, dan menyempit) maka dapat disimpulkan bahwa variabel kontrol diri, kesepian, dan nomophobia tidak terjadi heteroskedastisitas. Untuk uji multikolinieritas menunjukkan bahwa variable kontrol diri memperoleh nilai tolerance sebesar 0,963>0,10 dan VIF sebesar 1,038<0,10. Kemudian pada variabel kesepian memperoleh nilai tolerance sebesar 0,963 $>0,10$ dan VIF sebesar 1,038<0,10 yang mana hal ini dapat disimpulkan bahwa variabel kontrol diri dan kesepian tidak multilinieritas.

Setelah dilakukan uji prasyarat maka dapat dilanjutkan untuk uji hipotesis menggunakan analisis regresi linier berganda dengan bantuan SPSS for Windows versi 16.0. Pada hipotesisi yang pertama terdapat hubungan kontrol diri dengan nomophobia pada remaja. Dari hasil penelitian yang dilakukan terdapat nilai korelasi dengan nilai 0.137 sedangkan signifikansi memiliki nilai sejumlah 0,006. Hal ini menunjukkan bahwa nilai signifikansi lebih kecil dari 0,05. Maka H0 ditolah sedangkan Ha diterima. artinya terdapat hubungan yang signifikan ke arah positif antara kontrol diri dengan nomophobia pada remaja di SMAN 22 Surabaya, SMKN 12 Surabaya, dan MAN Kota Surabaya. Sehingga terbukti jika semakin tinggi kontrol diri maka akan semakin tinggi pula tingkat nomophobia pada remaja di SMAN 22 Surabaya, SMKN 12 Surabaya, dan MAN Kota Surabaya, dan sebaliknya jika semakin tinggi nomophobia maka semakin tinggi kontrol diri.

Hal ini sejalan dengan penelitian yang dilakukan oleh Hepri, Zuhdiyah, dan Ema, (2019) dengan judul Hubungan antara Kontrol Diri dengan Kecanduan Internet Pada Siswa Kelas XI SMA Negeri 16 Palembang dengan hasil analisis diperoleh besarnya koefisien korelasi antara kontrol diri dengan kecanduan internet sebesar $r=0,408$ dengan nilai signifikansi 0,000 dimana $p=<0,05$ maka hasil ini menunjukkan hasil bahwa kontrol diri mempunyai hubungan yang signifikan ke arah positif dengan kecanduan internet pada siswa kelas 11 SMA Negeri Palembang.

Penelitian ini memiliki hubungan ke arah positif, yang mana hal ini disebabkan oleh kasus Covid-19 yang melanda di berbagai sektor termasuk dunia pendidikan, terbukti hingga saat ini kegiatan belajar dan mengajar masih menggunakan metode jarak jauh atau yang biasa disebut dengan pembelajaran daring. Permasalahan yang terjadi saat ini yaitu proses pembelajaran yang terpaksa dilakuakan di rumah, sejak itu mulai terserap layar smartphone yang penggunaannya bisa sampai 5 jam ke atas setiap hari senin hingga jumat, demi mengikuti kegiatan belajar mengajar melalui Google Classrom, WhatsApp, dan aplikasi lain yang disediakan oleh sekolahan. Dilansir dari tirto.id mengatakan bahwa survey KPAI (Komisi Perlindungan Anak Indonesia) terkait dengan pelaksanaan proses belajar daring di 20 provinsi dan 54 kabupaten/kota menyebut 73,2\% siswa dari 1.700 responden, atau 1.244 siswa mengaku terbebani tugas dari pada guru. Sebanyak 1.323 siswa dari seluruh responden berkata sulit mengumpulkan tugas karena guru meminta mereka mengerjakan tugas dalam waktu yang singkat. sejak adanya pandemi yang ada di dunia termasuk di Negara Indonesia. Keputusan Kementerian Pendidikan dan Kebudayaan tentang proses kegiatan belajar mengajar dilakukan secara daring dalam rangka pencegahan penyebaran virus Covid-19 menjadi alternatif supaya kegiatan pembelajaran tetap berjalan dengan cara daring (Dede Rahmat Hidayat, dkk. 2020).

Dalam hal ini kontrol diri berperan dalam mengantur dan mengarahkan diri untuk dapat menggunakan smartphone sesuai dengan kebutuhan. Seperti yang diketahui dalam hasil pengolahan SPSS bahwa nilia korelasi yang diperoleh ke arah positif, yang artinya remaja di SMAN 22 Surabaya, SMKN 12 Surabaya, dan MAN Kota Surabaya memiliki tingkat kontrol diri yang baik akan tetapi hal ini juga tidak menutup kemungkinan tingkat nomophobia yang meningkat. Dikarenakan adanya kegiatan belajar mengajar secara daring yang semakin menambah jam penggunakan smaprtphone atau media bagi remaja di SMAN 22 Surabaya, SMKN 12 Surabaya, dan MAN Kota Surabaya apalagi pada jaman modern ini fasilitas smartphone semakin dilengkapi dengan fitur-fitur baru yang menjadikan penggunanya semakin tidak bisa lepas. Berbeda dengan situasi sebelum pandemi Covid-19 yang mana nomophobia masih menjadi sebuah hal yang tabu dan masih terdapat pembatasan dalam penggunaannya seperti pada saat sekolah tidak boleh mengaktifkan smartphone dan lain sebagainya.

Sarlito W. Sarwono \& Meinarno Eko A. (2009) menjelaskan bahwa kepatuhan adalah salah satu jenis dari pengaruh sosial, di mana seseorang menaati dan mematuhi permintaan orang lain untuk bertingkah laku tertentu karena adanya power. Power ini dapat diartikan sebagai suatu kekuatan atau kekuasaan yang mempunyai pengaruh terhadap seseorang atau lingkungan tertentu. Pengaruh sosial ini bisa memberikan dampak negatif ataupun positif terhadap perilaku individu tersebut. Sesuai dengan pembelajaran daring di masa pandemi ini yang mana siswa/sisiwi maupun lembaga dituntut untuk 
melakukan pembelajaran jarak jauh guna untuk mengurangi penyebaran virus Covid-19. Sesuai dengan pernyataan yang dikeluarkan oleh Kementerian Pendidikan dan Kebudayaan bahwa kegiatan belajar mengajar dilakukan secara dari sebagai alternatif supaya pembelajaran tetap berjalan.

Uji hipotesis kedua pada penelitian ini terdapat korelasi dengan jumlah nilai 0,288 sedangkan signifikansi memiliki nilai sejumlah 0,000. Hal ini menunjukkan bahwa nilai signifikansi lebih kecil dari 0,05. Maka H0 ditolah sedangkan Ha diterima. Yang artinya terdapat hubungan antara kesepian dengan nomophobia pada remaja. Hasil penelitian ini meberikan arti bahwa terdapat korelasi yang positif signifikan antara kesepian dengan nomophobia pada remaja di SMAN 22 Surabaya, SMKN 12 Surabaya, dan MAN Kota Surabaya. sehingga terbukti jika semakin tinggi Kesepian maka akan semakin tinggi pula tingkat Nomophobia pada remaja di SMAN 22 Surabaya, SMKN 12 Surabaya, dan MAN Kota Surabaya.

Hasil tersebut didukung dengan penelitian yang berjudul "hubungan kesepian dan nomophobia pada mahasiswa generasi Z" yang ditulis oleh Aida Nur Saripah \& Lila Pratiwi, (2020), menunjukkan hasil analisis pearson correlation .687 denagn probability value sejumlah 0.000 . hal ini menunjukkan terdapat korelasi yang positif signifikan antara kesepian dan nomophobia, dikarenakan probabilitynya di bawah 0.001. Oleh karena itu dapat dibilang semakin tinggi tingkat kesepian maka semakin tinggi juga tingkat nomophobia, sebaliknya jika semakin rendah tingkat kesepian maka akan rendah pula tingat nomophobia.

Hasil penelitian dari Wenny \& Selviana, (2020) juga mengatakan terdapat hubungan antara Kesepian dengan Kecenderungan Nomophobia Pada Remaja Kelas XI \&XII SMA Annajah dengan nilai korelasi 0.019 dan signifikansi dengan nilai 0,01 yang artinya $\mathrm{P}<0.05$, jadi bisa diambil sebuah kesimpulan terdapat hubungan signifikan ke arah positif antara kesepian dengan kecenderungan nomophobia pada remaja di kelas XI \&XII SMA Annajah. Yang memiliki arti bahwa semakin tinggi tingkat kesepian pada remaja maka tinggi pula tingkat nomophobia pada remaja di kelas XI \&XII SMA Annajah. Penelitian yang dilakukan oleh Ozdemir, Cakir, \& Hussain, (2017), yang berkaitan dengan nomophobia juga menunjukkan hasil korelasi positif yang signifikan tentang kesepian pada pelajar di Pakistan. Kemudian riset dari Durak, (2018) kepada 728 siswa juga mengungkapkan hubungan yang moderat diantara Nomophobia dan Kesepian.

Hal-hal tersebut di atas dikarenakan waktu yang digunakan untuk bermain smartphone merupakan sebuah gangguan yang berhubungan dengan nomophobia, selain itu lama penggunaan pada internet seluler juga mempunyai tingkatan moderat serta signifikansi yang berarti dengan nomophobia. (Gezkin, 2017). Menurut Gezkin, Hamutoglu, Sezan, \& Yildrim, (2019), menunjukkan peserta dengan gejala nomophobia digambarkan dengan perumpamaan yang membentuk kesepian dengan tanpa gadget menjadikan seseorang akan merasakan ketiadaan suatu hal yang penting serta berharga. Maka, dari sini dapat disimpulkan, nomophoba diduga sebuah keadaan yang negatif karena bisa menggangu kehidupan seseorang. Selain itu kesepian juga dapat memberikan sebuah stimulus kepada siswa/siswi untuk menggunakan smartphone lebih sering. Penggunaan smartphone akan lebih dirasakan oleh seseorang yang sedang kesepian dibanding seseorang dengan teman yang banyak. Sisw/siswi akan lebih sering berinteraksi dengan orang lain daripada dengan kontak smartphonenya.

Hal ini juga tidak jauh dari situasi dan kondisi dimasa pandemi Covid-19 yang masih cukup membatasi interaksi dengan orang lain, sehingga tidak sedikit yang masih membatasi dirinya untuk bertemu dengan teman sebaya. Adanya Pembatasan Sosial Berskala Besar (PSBB) menjadikan banyak remaja yang merasakan kesepian, yang nantinya akan menjadikan smartphone sebagai pelarian atau hiburan disaat jenuh. Kesepian merupakan sebuah kondisi yang tidak bisa dipisahkan dari aspek-aspek kehidupan. Karena merupakan sebuah bentuk permasalahan emosional yang bisa saja dialami oleh semua orang dengan kadar ringan dan berat yang berbeda setiap individu. Kesepian adalah sebuah kejadian yang berkembang dari persepsi seseorang terhadap kemampuan diri dalam merespon sebuah peristiwa atau situasi (Dony \& Dede, 2020).

Hipotesis ketiga dari penelitian yang dilakukan adalah terdapat nilai F-hitung dengan nilai 23.572. apabila tingkat keyakinan yang digunakan sebasar 95\%, a $=5 \%$ df (Degree of Freedom) 1 jumlah variabel-1 = 2 dan df (Degree of Freedom) $\mathrm{n}^{-\mathrm{k}}-1=343 . \mathrm{N}$ merupakan jumlah keseluruhan responden, kemudian k yaitu jumlah variabel bebas. Dari perhitungan di atas maka akan memperoleh nilai F-tabel dengan nilai 3,022. Dikarenakan nilai F-hitung lebih besar dari F-tabel maka H0 ditolak. Hal ini menunjukkan suatu hubungan antara kontrol diri dan kesepian dengan nomophobia pada remaja di SMAN 22 Surabaya, SMKN 12 Surabaya, dan MAN Kota Surabaya. Hasil penelitian ini memberikan 
arti bahwa terdapat korelasi positif yang signifikan diantara variabel kontrol diri dan kesepian dengan nomophobia pada remaja di sekolah SMAN 22 Surabaya, SMKN 12 Surabaya, dan MAN Kota Surabaya.

Dari analisis data dengan bantuan SPSS versi 16.0 diperoleh sumbangan efektif variabel kontrol diri dan kesepian dengan nomophobia pada remaja di SMAN 22 Surabaya, SMKN 12 Surabaya, dan MAN Kota Surabaya memiliki nilai sebesar R2 =0,121. Perhitungan sumbangan efektif (SE) masingmasing variiabel mengikuti rumus sebagai berikut: SE (X)\%=Betax X rxy X100\%. Dari rumus itulah dapat diketahui sumbangsih dari variabek kontrol diri adalah 2,7\% dari variabel kesepian adalah sebesar 9,4\%. Kedua variabel ini memberikan sumbangan efektif, namun sumbangan efektif yang diberikan oleh variabel kesepian lebih banyak dari pada kontrol diri. Selebihnya itu variabel nomophobia dipengaruhi oleh faktor-faktor lain yang tidak diungkap pada penelitian kali ini.

Empat faktor nomophobia menurut Yuwanto, (2010) diantaranya adalah: a. Faktor dari Dalam: faktor ini paling beresiko dalam penyebab seseorang yang menderita nomophobia diantara yaitu: sensation seeking yang tinggi, self-esteem yang rendah, dan kepribadian ekstraversi yang tinggi, serta kontrol diri yang rendah. Kontrol diri yang rendah ini selaras dengan hasil penelitian yang dilakukan oleh Asih dan Fauziah, (2017) yang menunjukan kontrol diri memenggambarkan sebuah factor yang memberikan sumbangan efektif sebesar 4,3\% pada nomophobia, b. Faktor dari Situasional: merupakan faktor penyebab dari seseorang yang ketergantungan pada smartphone sehingga smartphone menjadi sebuah media coping. Pada faktor ini diketahui dapat menggambarkan situasi psikologis seseorang yang mengarah kepada pemakaian smartphone seperti contohnya stress, kesepian, merasa sedih, kejenuhan dalam belajar, dan kecemasan, c. Faktor dari Sosial: kondisi yang mempengaruhi individu untuk selalu menggunakan smartphone karena sudah menjadi kebutuhan dan sarana untuk beromunikasi dengan individu lainnya, d. Faktor dari Luar: adanya faktor ini disebabkan paparan teknologi yang memberikan kecanggihan pada smartphone contohnya seperti terdapat beberapa fasilitas yang dimiliki oleh smartphone sehingga menjadikan seseorang untuk ingin memiliki dan menggunakan smartphone.

Selain faktor nomophobia yang telah disebutkan, berikut beberapa faktor yang dapat mempengaruhi nomophobia oleh Bianchi dan Philip, (2005): a). Gender: perbedaan gender adalah sebuah fungsi sosialisasi dan merupakan akses terhadap sebuah teknologi. dalam hal ini seorang pria kemungkinan memiliki sikap yang positif terhadap computer, dibandingkan dengan wanita. Jika dilihat secara logikanya pria akan lebih banyak problem dalam penggunaan smartphone ataupun teknologi lain dibandingkan dengan Wanita, b). Harga diri: di sini memiliki keterkaitan dengan identitas dan pandangan diri. Seseorang yang memiliki pandangan negatif akan cenderung untuk mencari kepastian, telepon gengam memberikan fasilitas kepada penggunanya untuk dapat dihubungi pada situasi yang tidak dibatasi, oleh karena itu dan dari sini tidak mengherankan apabila seseorang menggunakan smartphone berlebihan dan tidak tepat, c). Umur: penelitian yang sebelumnya mengatakan bahwa orang tua kurang memungkinkan dalam pengunaan teknologi baru dibandingkan dengan orang muda. Brickfield menemukan bahwa sebagian alasan dari orang tua cenderung kurang dalam pemakaian produk teknologi baru, d). Extraversi: merupakan keadaan yang rentan terhadap smartphone dikarenakan orang yang extraversi cenderung mencari sebuah situasi sosial. Extraversi lebih rentan berpengaruh terhadap teman sebaya, e). Neurotisme: seseorang yang neurotisme akan bereaksi kuat terhadap banyak rangsangan serta terlalu emosi. Beberapa tanda neurotisme adalah murung, cemas, mengkhawatirkan, sering mengalami depresi. Dari beberapa faktor di atas dan dari nilai R Square (Koefisien Determinasi) sebesar 0.121 yang artinya 12.1\% variabel nomophobia dipengaruhi oleh variabel kontrol diri dan kesepian. Sisanya sebesar 87.9\% dipengaruhi variabel lain.

Variabel nomophobia sudah banyak digunakan oleh beberapa peneliti sebelumnya termasuk yang membahas tentang intensitas penggunaanya pada media sosial berupa instagram, youtube, kecemasan hingga teknik penggunaan bimbingan kelompok guna mengurangi kecenderunagn nomophobia. Sedangkan kontrol diri dan kesepian menjadi tema yang masih jarang diperbincangkan di dalam bidang psikologi sosial dan pendidikan. Perbedaan yang ada dengan penelitian terdahulu dapat terlihat bahwa penelitian ini dilaksanakan dengan menggunakan tiga sekolahan berbeda dengan jenjang yang sama yaitu SMK, SMA, dan MAN dan situasi yang tidak biasa yaitu di tengan wabah pandemi Covid-19, yang mana subjek mulai dibiasakan dengan menggunakan smartphone untuk beberapa kebutuhan sebagai alternatif, selain itu penelitian ini pertama dilakukan dalam bidang psikologi pendidikan dan sosial. 


\section{Kesimpulan}

Hasil korelasi yang terdapat pada variabel kontrol diri dengan nomophobia mempunyai nilai koefisien korelasi (rxy) sejumlah 0,137 dengan signifikansi $p=0,006(p=0,006<0.05)$. maka, dapat diketahui bahwa ada hubungan kontrol diri dengan nomophobia pada remaja. Berdasarkan hasil korelasi pada variabel kesepian dengan nomophobia mempunyai koesifien korelasi (rxy) sejumlah 0,288 dengan $(\mathrm{p}=0,000<0,05)$ memberikan arti bahwa terdapat hubungan kesepian dengan nomophobia pada remaja. Berdasarkan hasil analisis regresi linier berganda diperoleh harga koefisien $\mathrm{F}=23.572$ pada $\mathrm{p}=$ 0.000 ( $\mathrm{p}>0.05$ ) sehingga kontrol diri dan kesepian secara bersamaan mempunyai hubungan yang signifikan dengan nomophobia.

Hal ini juga tidak jauh dari situasi dan kondisi saat masa pandemi Covid-19 dimana masih cukup membatasi interaksi dengan orang lain, sehingga tidak sedikit yang masih membatasi dirinya untuk bertemu dengan teman sebaya dan tidak sedikit dari remaja yang merasakan kesepian, yang menjadikan smartphone sebagai hiburan disaat jenuh.

\section{Daftar Pustaka}

Agusta, D. (2016). Faktor-faktor Resiko Kecanduan Menggunakan Smartphone pada Siswa Di SMK Negeri 1 Kalasan Yogyakarta. E-Journal Bimbingan dan Konseling Edisi 3 Tahun ke-5. Vol 3. No 5.

Aldianita, N., \& Maryatmi, A. S. (2019). Hubungan Kontrol Diri Dan Perilaku Impulsif Dengan Nomophobia Pada Remaja Pengguna Instagram Di Kelas Xi Ips Sman 31 Jakarta Timur. Jurnal IKRA-ITH Humaniora, 3(3), 188-196.

APJII. (2017). Infografis "Penetrasi dan Perilaku Pengguna Internet Indonesia Tahun 2017". Jakarta: Tekno Preneur

Aprilia, Nadia. (2020). Pengaruh Kesepian dan Kontrol Diri Terhadap Kecenderungan Ketergantungan Terhadap Ponsel. Psikoborneo, Vol 8, No 2. 249-254.

Asih, A. T., \& Fauziah, N. (2017). Hubungan Antara Kontrol Diri Dengan Kecemasan Jauh Dari Smartphone (Nomophobia) Pada Mahasiswa Jurusan Ilmu Komunikasi Fakultas Ilmu Sosial Dan Politik Universitas Diponegoro Semarang. Empati, 6(2), 15-20.

Bianchi A \& Phillips JG. (2005). Psychological predictors of problem mobile phone use. Journal of Cyber Psychological Behaviour, 8, 39-51

Bivin, J.B., Mathew, P., Thulasim P.C. Philip, J. (2013). Nomophobia Do We Healty Neet to Worry About? Review of Progress. Vol. 1 Issue 1.

Ciptadi, Wenny Achnashinta \& selviana. (2020). Hubungan Antara Kepribadian Ekstraversi dan Kesepain Dengan Kecenderungan Nomophobia Pada Remaja. Jurnal IKRA-ITH Humaniora. Vol 4. No 3.

Durak, H. Y. (2018). What would you do without your smartphone? Adolencents social media usage, locus of control and loneliness as a predictor of nomophobia. Addicta: The Turkish Journal An Addictions. Doi: 10.15805/Addicta.2018.5.2. 0025

Gezgin D.M. (2017). Exploring the influence of the patterns of mobile internet use on university students' nomophobia levels. European Journal of Education Studies. Doi: 10.5281/Zenodo.572344.

Gezgin, D. M., Hamutoglu, N.B., Sezen-Gultekin, G., \& Yildirim, S. (2019). Preservice Teachers metaphorical perceptions on smartphone, no mobile phone phobia (Nomophobia) and fear of missing out (FOMO). Bartin University Journal of Faculty of Education, 8 (2), 733-783. Doi: 10.14686/Buefad. 516540.

Hidayat, Dede Rahmat, dkk. (2020). Kemandirian Belajar Peserta Didik dalam Pembelajaran Daring Pada Masa Pandemi Covid-19. Jurnal Perspektif Ilmu Pendidikan. Vol 34. No 2.

https://tirto.id/stres-burnot-jenuh-problem-siswa-belajar-daring-selama-covid-19-f3ZZ. 
Hurlock, Elizabeth B. (2011). Psikologi Perkembangan: Suatu Pendekatan Sepanjang Rentang Kehidupan. Jakarta: Erlangga.

Kail, R, V \& Cavanaugh, J, C. (2010). Human Develompent-a Life Span View. $5^{\text {th }}$ edition. Belmont, USA. Wadsworht, Cengange Learning.

Kail, R, V \& Cavanaugh, J, C. (2010). Human develpoment-a life span view. 5th edition. Belmont, USA. Wadsworht, Cengage Learning.

Karnadi, Hepri. Zuhdiyah. \& Yudiani, Ema. (2019). Hubungan antara Kontrol Diri dengan Kecanduan Internet Pada Siswa Kelas XI SMA Negeri 16 Palembang. Jurnal Intelektualita: Keislaman, Sosial, dan Sains. Vol 8. No 2.

Muhid, Abdul. (2012). Analisis Statistik. Sidoarjo: Zifatma Jawara

Mutawally. (2020). Konseling Realitas dan Nomophobia: Kajian Pengantar Tentang Konsep, Aplikasi dan Tantangan. Jurnal Idrak Journal of Islamic Education. Vol 2. No 2.

Ozdemir, B., Cakir, O., \& Hussain, I. (2017). Prevalence of nomophobia among university students: comparative study of pakistani and turkish undergraduate students. Eurasia Journals of Mathematics, Science and Technology Education. Doi: 10.29 333/Ejmste/8483932.

Peplau, L.A dan Perlman, D. (1982). Loneliness: A. SourceBook of Current Theory, Reseach, And Therapy. New York: John Willy \&Sans.

Permatasari, I., Yusmansyah, Y., \& Widiastuti, R. (2019). Penggunaan Bimbingan Kelompok Teknik Self Management untuk Menurunkan Kecenderungan Nomophobia Siswa SMA. Alibkin (Jurnal Bimbingan Konseling), 7(5).

Permatasari, Intan., Yusmansyah., \& Widiastuti, Ratna. (2019). Penggunaan Bimbingan Kelompok Teknik Self Management Untuk Menurunkan Kecenderungan Nomophobia Siswa SMA. ALIBIKIN (Jurnal Bimbingan Konseling). Vol 7. No 5.

Rahayuningrum, Dwi Christina \& Annisa Novita Sary (2019). Studi Tingkat Kecemasan Remaja Terhadap No-Mobile Phone (Nomophobia) Di Sma Negeri Kota Padang. Ensiklopedia of Journal. Vol. 1 No.2

Ramaita, R., Armaita, A., \& Vandelis, P. (2019). Hubungan Ketergantungan Smartphone Dengan Kecemasan (Nomophobia). Jurnal Kesehatan, 10(2), 89.

Saripah, Nur Aida \& Pratiwi, L. (2020). Hubungan kesepian dan nomophobia pada mahasiswa generasi z. Jurnal Ilmiah Penelitian Psikologi: Kajian Empiris \& Non-Empiris, 6(1), 35-46.

Sarwono, Sarlito W. \& Eko A. Meinarno. (2009). Psikologi Sosial. Jakarta: Penerbit Salemba Humanika.

Segita, Dony Darma \& Hermawan, Dede. 2020. Kesepian Remaja Pada Masa Pandemi Covid - 19. Enlighten: Jurnal Bimbingan Konseling Islam. 3(2). 122-130.

Tan, C, Pramuk, M, \& Donder, A. (2013). Loneliness and Mobile Phone. Procedia-Social and Behavioral Scinces, 103(2013), 606-611.

Tangney, J.P., Baumeister, R, F., Boone, F.L. (2004). High Self Control Predicts Good Adjustment, Less Pathology, Better Grades, and Interpersonal Success. Journal of Personality, 72 (2), 271-324.

Yuwanto, L. (2010). Cause of Mobile Phone Addiction. Anima Indonesia Psychological journal. 25(3), 225-229. 